\title{
Synergiczna pełnia współczesnej architektury willowej w przestrzeni miasta
}

\author{
Monika Gala-Walczowska \\ Katedra Architektury Mieszkaniowej i Kompozycji Architektonicznej, \\ Instytut Projektowania Architektonicznego, Wydział Architektury, Politechnika Krakowska, \\ e-mail:mgala-walczowska@pk.edu.pl
}

Streszczenie: Przestrzenią szczególną w krajobrazie historycznych miast europejskich jest dzielnica willowa, której urodę i prestiż współtworzą walory naturalne, kompozycja urbanistyczna, a nade wszystko jakość architektury. Zarówno w przeszłości, jak i współcześnie, architektura willi miejskiej powiązana była z ogrodem i miała charakter reprezentacyjny. Synergiczna pełnia współczesnej architektury willowej budowana jest przez ponowoczesną interpretację miejsca, którego charakter niejednokrotnie skłania architektów do poszukiwania związków budowli z terenem i otaczającym krajobrazem, w przestrzennej i widokowej łączności z miastem lub przeciwnie, poprzez wizualne odseparowanie od ulicy lub selektywne kadrowanie widoków. Jakość prezentowanych przykładów współczesnej architektury willowej definiowana jest przez indywidualizm twórców. Każdy z architektów inaczej interpretuje miejsce, proponując stosowną formę architektoniczną domu w przestrzeni dzielnicy willowej miasta. Ceglana willa w Berlinie, projektu Davida Chipperfielda, to architektura symbiotycznej petni z miejscem. House R128, w dzielnicy willowej Stuttgartu jest przykładem architektonicznej gry z miejscem, kreowanej przez architekta, a zarazem właściciela willi Wernera Sobka. House Susenberg, w prestiżowej dzielnicy willowej Zürichu, determinuje dialog architektury z przestrzenia miasta. Architekturę Willi Băteau-Băteau w Krakowie, autorstwa Dariusza Kozłowskiego i Marii Misiągiewicz, można określić mianem znaku w przestrzeni dzielnicy willowej. Synergiczna pełnia współczesnej architektury willowej w krajobrazie miasta stanowi o unikalnej jakości przestrzeni, nazywanej Duchem Miejsca.

Słowa kluczowe: architektura współczesna, willa miejska, forma i kompozycja architektoniczna, synergia w architekturze.

Znaczenia nabrało miejsce $w$ mieście, które może domagać się architektonicznej formy [1].

Dariusz Kozłowski

\section{Charakter miejsca a architektura współczesnej willi miejskiej}

Synergia w architekturze jest wypadkową współdziałania wielu czynników: walorów naturalnych i kulturowych miejsca, formy i kompozycji architektonicznej, w relacji do programu, doboru materiałów, sposobu wkomponowania bryły w przestrzeń naturalną lub zurbanizowaną, zwielokrotnioną przez ich równoczesne występowanie. Powstaje wówczas 
owa wartość dodana - suma synergiczna, będąca efektem wzajemnego potęgowania oddziaływania poszczególnych elementów, nade wszystko syntezy miejsca i architektury

Przestrzenią szczególną historycznych miast europejskich, o długiej tradycji i prestiżu jest dzielnica willowa, której charakter współtworzą walory naturalne, kompozycja urbanistyczna, a nade wszystko jakość poszczególnych dzieł architektury. Właśnie w tej przestrzeni, gdzie intensywność zabudowy jest mniejsza, znaczenia nabiera dynamika relacji architektury i miejsca, zasadzona na związkach estetycznych i przestrzennych między formą architektoniczną willi, definiowaną przez zasadę kompozycyjną, a topografią terenu, zielenią, niekiedy wodą ... Doniosłość tej zależności potwierdzają słowa Chrystiana Norberg'a-Schulz'a: poziom krajobrazu to „grunt”, na którym rozwinęty się konfiguracje przestrzeni egzystencjalnych, struktura domu to przede wszystkim struktura miejsca [2]. Architektura willi wiążąc się z konkretnym miejscem w przestrzeni miasta, przejmuje coś z jego charakteru, nadając mu jednocześnie nowe znaczenie [3]. Idea architektoniczna i kształt architektury willi, mają swój rodowód w umyśle twórcy, w subiektywnej analizie uwarunkowań wywodzących się z kontekstu, w rzeczywistych motywacjach lub pretekstach architektonicznych, które jak wyjaśnia Dariusz Kozłowski, mogą stanowić „zmyślone powody” poddane dla ukrycia właściwej przyczyny [4]. Analizując topografię terenu, kształt działki, szatę roślinną, orientację względem stron świata, walory widokowe lub świadomie ignorując zastaną rzeczywistość, architekt kreuje w wyobraźni, szkicach, rysunkach, a następnie w realnej przestrzeni miasta ,architektoniczny scenariusz", tworząc symbiotyczną, neutralna lub kontrastowa relację architektury i miejsca. Zespolenie, gra lub skontrastowanie architektury willi z otoczeniem, sprzyja naturalnej potrzebie identyfikacji mieszkańców, decydując o tożsamości przestrzeni. Charakter w odniesieniu do przestrzeni oznacza miejsce w sensie indywidualnego „tutaj”, co pomaga człowiekowi zdobyć egzystencjalne oparcie [2, 219], dzięki czemu ludzie identyfikują się z miejscem i architekturą.

Architektura willowa stała na przestrzeni dziejów w centrum architektonicznych poszukiwań. Współcześnie, podobnie jak to miało miejsce w przeszłości, znaczenie architektury willowej, czytelne jest w formie architektonicznej, pojmowanej jako reprezentacja siedziby człowieka i godności zamieszkiwania. Przywołując słowa Antonio Monestirolego: chodzi o przedstawienie, przy pomocy form architektonicznych, sensu budynku, tej najgłębszej racji jego istnienia, która nie zawsze daje się odkryć. To dązenie reprezentatywne odróżnia architekturę od każdej innej konstrukcji [5]. Poprzez sposób kształtowania bryły, kompozycję elewacji, skalę, dobór materiałów, architektura willi może nabierać cech monumentalnych i potęgować swoją wartość formalną, podkreślając status właściciela.

Architektura współczesnej willi miejskiej wpisuje się w pluralistyczną rzeczywistość architektoniczną, której celem jest dążenie do nadania indywidualnego charakteru budynkom i miejscom [6]. Różnorodność architektonicznych konwencji współczesnej architektury, także architektury willowej, ma związek z niemożnością wskazania jednego obowiązującego współcześnie stylu. Przeciwnie, bogactwo form architektury współczesnej łączy się z indywidualizmem poszczególnych twórców. Architektura i cała sztuka dziś nie jest już wyrażeniem plastycznym jakiegoś określonego ideału, zauważa Dariusz Kozłowski, jest wyrażeniem każdego ideatu, któremu twórca potrafi nadać formę. Nie ma, więc kierunków

${ }^{1}$ Artykuł inspirowały fragmenty pracy doktorskiej Architektura domu jednorodzinnego w krajobrazie, M. Gała-Walczowska, napisanej pod kierunkiem Pani prof. dr hab. inż. arch. Marii Misiągiewicz, w Katedrze Architektury Mieszkaniowej i Kompozycji Architektonicznej, Wydziału Architektury Politechniki Krakowskiej 
architektury, jest tylko oryginalność wielkich twórców [7]. Jakość prezentowanych przykładów stanowiona jest poprzez subiektywną, a zarazem kreatywną interpretację miejsca, odzwierciedloną w architekturze współczesnej willi w przestrzeni miasta.

\section{Willa w Berlinie - symbioza architektury i miejsca}

W latach 1994-96, w prestiżowej dzielnicy willowej, położonej w południowozachodniej części Berlina, zbudowano willę zaprojektowaną przez Davida Chipperfield'a. Wybrano miejsce na granicy miasta i natury, gdzie pomiędzy otaczającą zieleń i jeziora wpisuje się zabudowa. Parcela o kształcie wydłużonego rombu, od strony zachodniej graniczy z drogą. W tej części teren jest wypłaszczony, podczas gdy część ogrodowa jest wyniesiona o około $3 \mathrm{~m}$ ponad poziom drogi. Różnica poziomów pomiędzy wejściową, a grodową częścią posesji, inspirowała architekturę i została uwzględniona w sposobie wkomponowania willi w to miejsce - bryłę zintegrowano z rozrzeźbioną topografią.

Formę architektoniczną willi wywiedziono z prostopadłościanu, o podstawie zbliżonej do kwadratu i wysokości trzech kondygnacji, z której odjęto południowo-zachodni narożnik. W wydrążonej przestrzeni umieszczono zaciszny, nasłoneczniony dziedziniec, wokół którego zorganizowano przestrzeń rodzinną. Program użytkowy rozmieszczono na 3 poziomach. W przyziemiu umieszczono pokoje gościnne, basen, saunę, pomieszczenia gospodarcze i garaż. Wokół dziedzińca, na parterze, zaplanowano: kuchnię, jadalnię i pokój dzienny. Poziom piętra mieści pokoje prywatne oraz przestrzeń klubową.

Pomimo wyboru konstrukcji żelbetowej, o odbiorze tej architektury decyduje cegła klinkierowa, która jest dominującym materiałem wykończeniowym willi. Wykończenie cegła dodaje domowi solidności, przypominającej wczesnomodernistyczne domy Ericha Mendelsona i Miesa van der Rohe, wyjaśnia David Chipperfield, nieregularność faktury ręcznie robionej cegły, wzmacnia efekt kontrastu z gładkościa i regularnościa szklanych tafli $^{2}$. Chropowatą fakturę i naturalną barwę cegły skontrastowano z gładkimi taflami szkła. Także schody terenowe, tarasy i murki, wyłożono cegłą klinkierową, zespajając przestrzennie i estetycznie, architekturę willi z terenem.
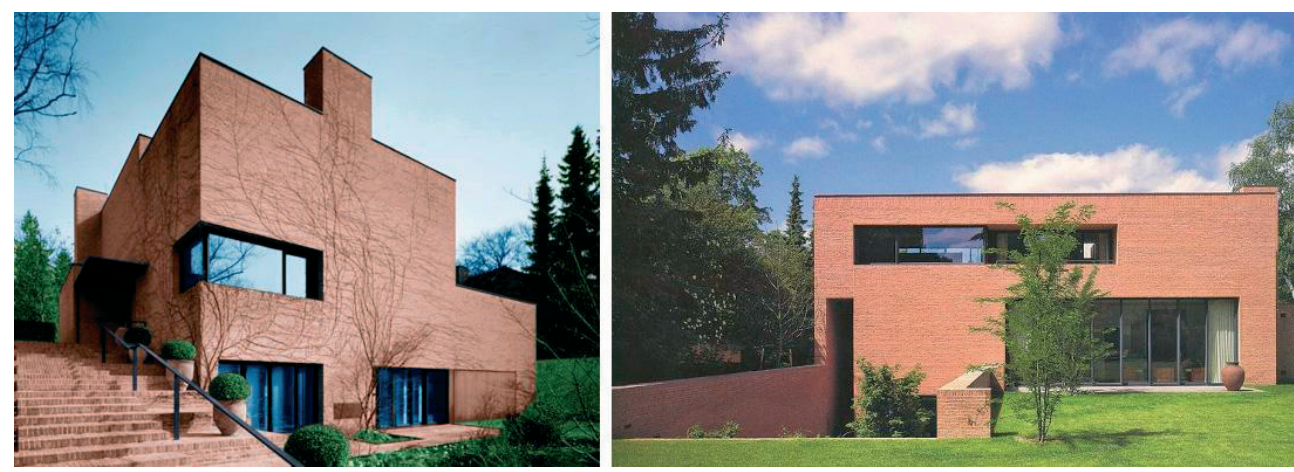

Rys. 1. Willa w Berlinie, Niemcy, 1994-96, David Chipperfield, widok od strony ulicy, widok od ogrodu, źródło: www.davidchipperfield.co.uk

${ }^{2}$ D. Chipperfield, opis autorski, [źródło:] www.davidchipperfield.co.uk, [data dodania: 10.08.2012] 
Kompozycja elewacji została podporządkowana „kadrowaniu” widoków oraz łączności wnętrza willi z ogrodem i otaczającym krajobrazem. Każda z elewacji odczytywana jest jako abstrakcyjna kompozycja, definiowana poprzez kształt, proporcje i sposób rozplanowania wycięć, wnęk i przeszkleń, na tle ceglanej ściany. Od strony wejściowej willa sprawia wrażenie nieprzystępnej. O takim odbiorze decyduje kompozycja elewacji frontowej, zaplanowanej jako pełna ceglana ściana z jedynym narożnikowym oknem, widocznym ponad murem izolującym budynek od ulicy. Przeszklenia umieszczone w przestrzeni wydrążonego narożnika bryły, sprawiają, że część rodzinna wizualnie i przestrzennie łączy się z dziedzińcem. Na poziomie piętra sypialnie otwierają się na zacienione loggie.

Architektura willi odczytywana jest nade wszystko poprzez proporcje ideowej bryły prostopadłościennej, wkomponowanej w rozrzeźbioną topografię. Nadrzędna zasada kompozycyjna, polegająca na wycinaniu i drążeniu, odejmowaniu, stanowi o szczególnej zależności pomiędzy abstrakcyjną pustką przestrzeni wycięć i wnęk, a masą bryły budynku. Cegła klinkierowa, zgodnie z autorskim zamierzeniem, nawiązuje do dokonań modernistycznej awangardy, nadając solidny wyraz tej architekturze. Cegła przez swą plastyczność wzbogaca formę wspartą na geometrii. Zintegrowanie bryły ze zróżnicowanym ukształtowaniem terenu, stanowi o zespoleniu willi z miejscem i jakości architektury, nadającej znaczenie, a zarazem tożsamość lokalizacji.

\section{House R 128 w Stuttgarcie - architektoniczna gra z miejscem}

Willa zrealizowana w latach 1999-2000, na obrzeżach Stuttgartu, to szczególny przypadek, bowiem House $R 128$ w założeniu został zaprojektowany jako własny dom architekta Wernera Sobka. Parcela położona na jednym ze wzgórz, charakteryzuje się niecodziennym ukształtowaniem terenu. W górnej części jest to skarpa opadająca w kierunku zachodnim, poniżej - tarasowe wypłaszczenie. Dojazd zapewniony jest drogą przebiegającą od strony wschodniej, powyżej tego miejsca. Także w tym przypadku warunki lokalizacji inspirowały sposób wpisania bryły budynku w rozrzeźbioną konfigurację terenu. Willę postawiono na wypłaszczeniu zbocza, poniżej poziomu drogi.

Prostopadłościenna bryła o rzucie zbliżonym do kwadratu i wysokości czterech kondygnacji określa formę architektoniczną willi. Proporcje bryły sprawiają, iż przywodzi ona na myśl szklaną wieże mieszkalną. Poziom wejściowy zaplanowano nietypowo - na najwyższej kondygnacji. Metalowy pomost przerzucony pomiędzy ścieżką wydrążoną w skarpie, a kondygnacją wejściową, komunikuje dom z poziomem drogi. Program został opracowany dla dwóch osób, zamieszkujących na powierzchni $250 \mathrm{~m}^{2}$. W tym domu nie ma wydzielonych pokoi, ale 4 poziomy o otwartym planie. Na najwyższej kondygnacji umieszczono część recepcyjną, kuchnię i jadalnię, na kolejnych poziomach: przestrzeń wypoczynkową, sypialnię, a na najniższym poziomie pracownię architekta, otwierającą się na taras skomunikowany z ogrodem.

House R 128 zbudowano z elementów prefabrykowanych. Konstrukcja szkieletowa stalowe słupy i belki tworzą przestrzenną siatkę modularną, składającą się z 24 modułów. O niecodziennym charakterze architektury willi decydują szklane ściany, eksponujące stalową konstrukcję oraz znoszące wizualną barierę pomiędzy wnętrzem, a zewnętrzem, dając wrażenie bezkresu przestrzeni mieszkalnej, otwierającej się na cztery strony świata. Wnętrze willi pozostaje w wizualnej łączności z panoramą miasta, a szklane ściany pozwalają na wgląd do wnętrza. W płaszczyznach stropów prostokątne moduły wypełniono prefabrykowanymi drewnianymi oraz aluminiowymi panelami, a niektóre z modułów 
pozostawiono otwarte, pozwalając na wzrokową i akustyczną łączność pomiędzy poziomami użytkowymi.

Minimalistyczny projekt sprawia, że budowla jest bardziej interesujaca, pisze Philip Jodidio, zapomina się o aspektach technicznych $i$ to stanowi sukces tego przedsięwięcia[8]. Architektura willi nie epatuje technologią. Przeciwnie, lapidarna forma skrywa zaawansowane rozwiązania mające na celu oszczędność energii, pozwalając użytkownikom i odbiorcom skupiać się na walorach estetycznych architektury. W tym przełomowym domu dwudziestego pierwszego wieku, Werner Sobek taczy dwie największe fascynacje współczesnej architektury: prefabrykację i zrównoważenie, zauważa Dominic Bradbury, House $R 128$ to robiaca wrażenie architektoniczna wypowiedź, zawarta $w$ formie czterokondygnacyjnej szklanej kostki[9], mistrzowsko wkomponowanej w niecodzienna konfigurację terenu. To architektura pozwalająca na czerpanie $\mathrm{z}$ walorów miejsca $\mathrm{w}$ wizualnej łączności z krajobrazem miasta.
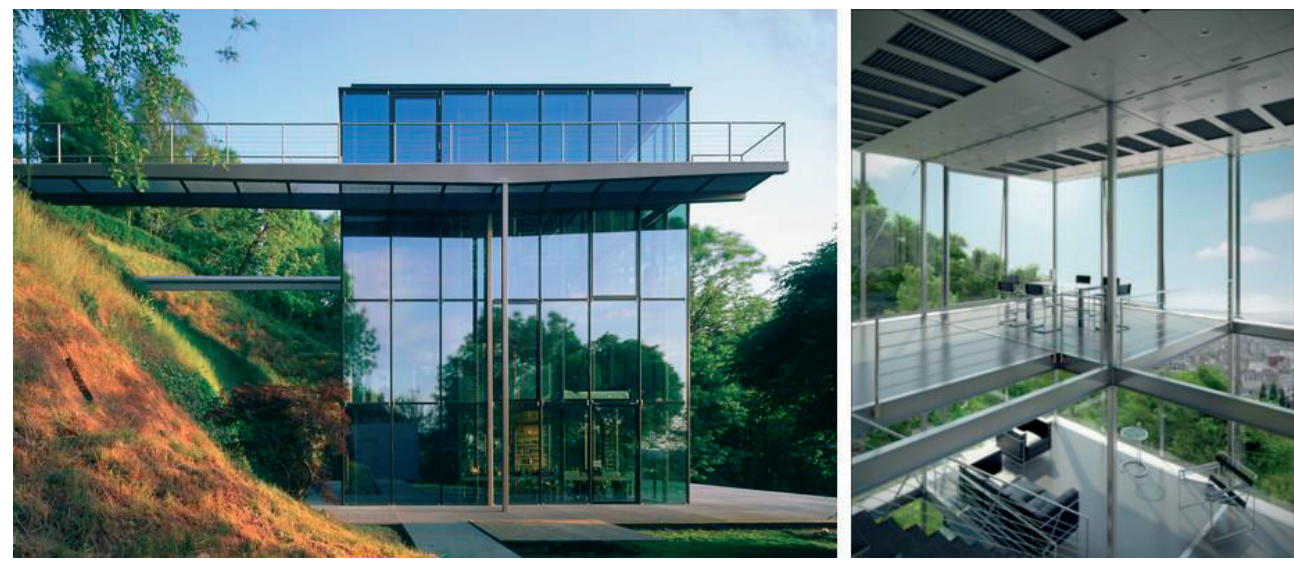

Rys. 2. House R 128, Werner Sobek, Stuttgart, Niemcy, 1999-2000, widok, wnętrze willi, fot. Roland Halbe, źródło: www.wernersobek.com

\section{House Susenberg $w$ Zürichu - dialog architektury z miastem}

Thomas Wild i Sabine Bär zaprojektowali House Susenberg zrealizowany w roku 2004, na obrzeżach Zürychu. O nastroju tamtejszego krajobrazu decydują wzgórza dopełnione przez Jezioro Zuryskie oraz rzeki Limmat i Sihl. Od strony południowej nad miastem góruje panorama Alp. Naturalne walory tego miejsca przyczyniły się do rozwoju dzielnicy willowej, usytuowanej na graniczącym z lasem południowo-zachodnim zboczu, z widokiem na jezioro. Parcela, o kształcie wydłużonego czworokąta, ma bezpośredni dojazd z ulicy, przebiegającej od strony północnej. W pobliżu drogi teren jest wypłaszczony, podczas gdy w głębi posesji opada on w kierunku południowo-zachodnim. Zbudowanie willi w tym miejscu wiązało się ze spełnieniem zaleceń dotyczących usytuowania budynku, wysokości bryły oraz zwartej formy, o podstawie kwadratu, nieograniczającej widoku na jezioro sąsiednim budynkom [10]. Zgodnie z tymi zaleceniami willę usytuowano w pobliżu drogi.

Forma architektoniczna willi powstała przez rozrzeźbienie prostopadłościennej bryły, o proporcjach zbliżonych do sześcianu i wysokości pięciu kondygnacji, wpisanej w zbocze. Ideowa bryła została zdekomponowana przez wycinanie narożników w przy- 
ziemiu, na poziomie parteru i na najwyższym poziomie. Dwie dolne kondygnacje, mieszczące pomieszczenia gospodarcze, pracownię i część rodzinną, wpisano w zbocze od strony północnej, a otwarto na widokową stronę ogrodową. Na najwyższym poziomie o rzucie krzyża, usytuowano sypialnię, w wydrążonych narożnikach umieszczono tarasy widokowe, pozwalające na rozkoszowanie się panoramą miasta, jeziora i gór.
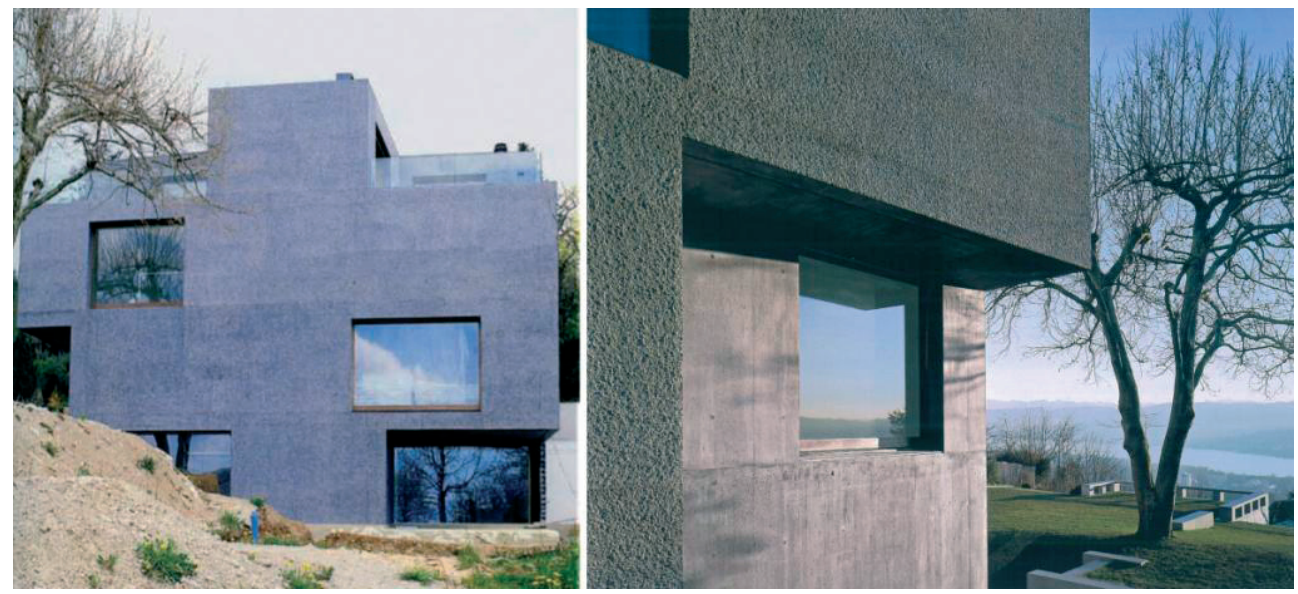

Rys. 3. House Susenberg, Wild Bär Architekten AG, Zürich, Szwajcaria, 2004, widok, fragment willi, fot. Roger Frei [w:] Baumeister/2007/9

Niecodzienna forma willi została wymodelowana w betonie. Żelbetową konstrukcję dopełniają betonowe płaszczyzny elewacyjne, potęgujące rzerźbiarskość bryły[11]. Zastosowano specjalnie przygotowaną mieszankę betonu, żwiru i czarnego pigmentu, dzięki której uzyskano antracytowy odcień płaszczyzn elewacyjnych, poddanych obróbce mechanicznej w celu otrzymania kontrastowych - aksamitnych i chropowatych faktur. Kompozycję rozrzeźbionych przez wycięcia elewacji dopełniają duże tafle szklane, swobodnie rozmieszczone na ścianach willi i w płaszczyznach wycięć.

$\mathrm{O}$ architekturze willi w Zürychu Hubertus Adam pisze: wycięcia w punktach wierzchołkowych podkreślaja rzeźbierska koncepcję, ale przede wszystkim przyczyniają się do zrelatywizowania idealnej geometrii platońskiej bryty na korzyść usytuowania nawiązujacego do miejsca[11]. Architektura willi stanowi odpowiedź na charakter krajobrazu i nastrój miejsca, położonego na granicy miasta i natury. Forma architektoniczna willi podporządkowana zaleceniom dotyczącym budowania $\mathrm{w}$ tej lokalizacji, pozwala zleceniodawcom, a także mieszkańcom zabudowy willowej w sąsiedztwie, na czerpanie z walorów tego miejsca.

\section{Willa Băteau-Băteau w Krakowie - znak w przestrzeni dzielnicy willowej}

Willa Bâteau-Bâteau w Krakowie, została zbudowana w latach 1992-96, według projektu Dariusza Kozłowskiego i Marii Misiągiewicz. Wybrano miejsce o szczególnych walorach krajobrazowych, w sąsiedztwie Rudawy i Krakowskich Błoń. Od strony północnej posesja przylega do ul.Emaus. Betonowy mur wyznacza granicę pomiędzy drogą, a terenem prywatnym. Parcela o powierzchni 7 arów i kształcie wydłużonego czworokąta 
inspirowała kompozycję architektoniczną: domy ułożono jeden za drugim, wyjaśniają autorzy, uzyskano z jednej strony zespolenie formy, z drugiej zupetna izolację obu części takiej całości [12].

Forma architektoniczna willi została wywiedziona z wydłużonej, rozrzeźbionej bryły prostopadłościennej o wysokości trzech kondygnacji i jest efektem kompozycji dwóch niezależnych części. Dekompozycja ideowej bryły ma związek z romantyczną ideą Domu Statku - formą reprezentacyjną, tajemniczą i teatralną, a wnętrzem willi dającym poczucie bezpieczeństwa i prywatności. Postużono się pewnym spójnym językiem form demonstracyjnie oddzielajac zewnętrzna, reprezentacyjna i oczywista powtokę Statku od niedostępnego dla widza wnętrza3.
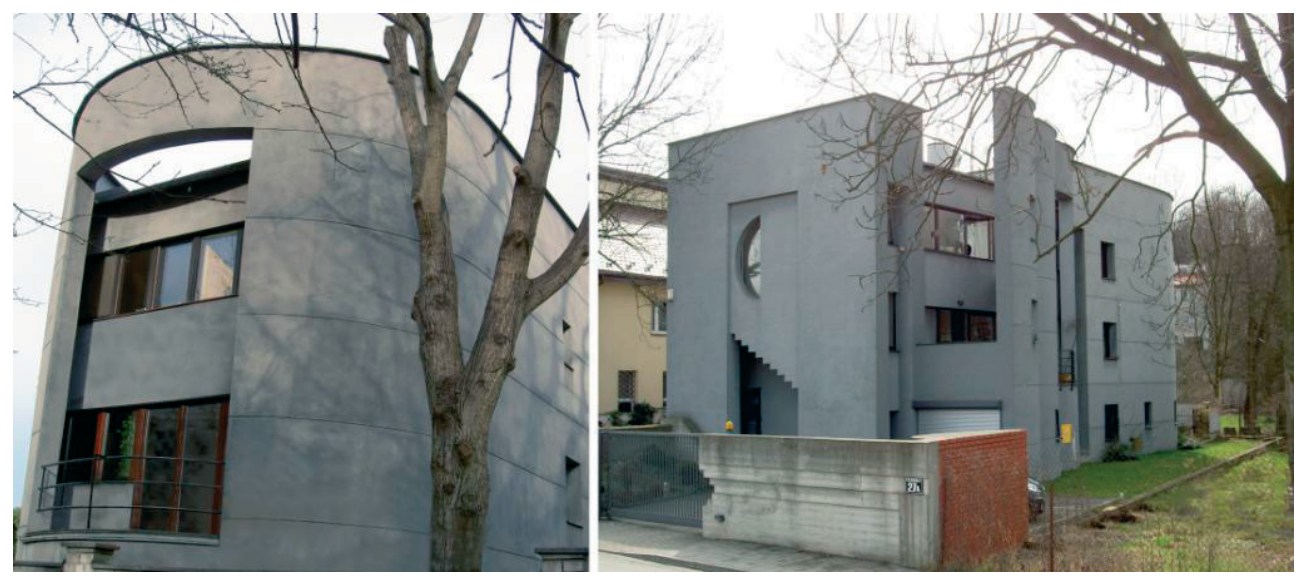

Rys. 4. Willa Băteau-Băteau, Dariusz Kozłowski, Maria Misiągiewicz, Kraków, Polska, 1992-96, widok od południa, widok od ul.Emaus, fot. autorka

Chociaż bryłę willi odbiera się jako formę jednorodną, to projektowane są dwie niezależne przestrzenie użytkowe, o zbliżonym programie. Na poziomie przyziemia umieszczono odrębne wejścia i garaże, usytuowane od strony północnej i wschodniej. W przyziemiu każdej z części znajduje się hall, pokój gościnny oraz pomieszczenia gospodarcze. Poziom pierwszego piętra mieści przestrzeń rodzinną, połączoną z kuchnią i jadalnią. Na najwyższej kondygnacji usytuowano pokoje prywatne. Pomimo bezpośredniego sąsiedztwa każdy z właścicieli czuje się swobodnie w swojej części, bowiem każdy z domów ma niezależną i zróżnicowaną stronę widokową - wnętrza części wspólnych oraz sypialni otwierają się na stronę zachodnią i południową.

W architekturze willi posłużono się symboliką autonomicznych konstrukcyjnie i funkcjonalnie, ale nade wszystko formalnie, ścian zewnętrznych. Elewacje: północna, południowa oraz zachodnia, zostały zakomponowane na dwóch planach. Pośrodku elewacji północnej wycięto wnękę, w której widoczny jest zewnętrzny obrys schodów, doświetlonych przez półkoliste okno. Elewacja zachodnia została zdwojona i rozrzeźbiona. Pierwszy plan tworzy falująca ściana, odchylona o kąt $30^{\circ}$. O jej charakterze stanowi niecodzienny kształt, a także zróżnicowanej wielkości wycięcia. Drugi plan, zakomponowano na rzucie kwadratu, a jest on odczytywany poprzez pasmowe okna kondygnacji

3 D. Kozłowski, opis autorski, [źródło:] http://www.dariuszkozlowski.arch.pk.edu.pl/projekty/bateau.htm [data dodania: 07.03.2016] 
mieszkalnych. Oba plany łączą się w poziomie przyziemia, a stropodach tej części willi przeznaczono na taras. Falująca, powycinana ściana kadruje widoki na otaczający krajobraz, a jednocześnie osłania taras od zabudowy w sąsiedztwie. Także elewację południową zakomponowano na dwóch planach. Pośrodku zewnętrznej płaszczyzny na łuku, umieszczono loggię. O nastroju tej architektury decyduje wszechobecna szarość. Okrętowy detal balustrad i horyzontalny rytm bonii podkreślają wydłużony kształt bryły.

Forma architektoniczna willi, monochromatyczna kolorystyka, sposób rozrzeźbienia bryły i kompozycja elewacji stanowią o zmienności widoków, a zarazem teatralnym charakterze willi. Niecodzienna forma architektoniczna dopełniona przez szarość sprawia, że willa jest akcentem - autorskim znakiem pośród zieleni i otaczającej zabudowy.

\section{Synergiczna pelnia architektury willowej w przestrzeni miasta}

Synergiczna pełnia współczesnej architektury willowej jest efektem ponowoczesnej interpretacji miejsca. Miasto, dzielnica willowa wraz z uwarunkowaniami lokalizacji mogą stanowić inspirację lub pretekst dla architektury. Powiqzania natury fizycznej i sentymentalnej sprawiaja, że ksztalt miasta odbierany jest jako catość, jedyna w swoim rodzaju, zauważa Maria Misiągiewicz, poddawana nieustannej metamorfozie staje sie przestrzenia estetycznie otwarta, pozwalająca odczytywać sens interwencji kompozycyjnych, rozeznawać walory ksztaltów rzeczy i miejsc, wczuwać się w magię gry kolorów, faktur, światel, cieni, dźwięków ...[13]. Charakter miejsca niejednokrotnie skłania architektów do poszukiwania związków willi z terenem i otaczającym krajobrazem, w przestrzennej i wizualnej łączności z miastem lub przeciwnie, poprzez odseparowanie od ulicy lub kadrowanie widoków.

Jakość prezentowanych przykładów współczesnej architektury willowej definiowana jest przez indywidualizm twórców. Przywołując słowa Dariusza Kozłowskiego: wciąż potwierdzana jest rola wyobraźni twórczej architekta jako najważniejszy czynnik sprawczy, w sytuacji gdy to miejsce szuka formy ...[1]. Zrodzona w umyśle architekta myśl, a następnie idea decyduje o formie architektonicznej i sposobie wkomponowania willi w miejsce. Każdy z współczesnych twórców architektury inaczej interpretuje kontekst, proponując stosowną formę architektoniczną willi w przestrzeni miasta. Forma architektoniczna wsparta nadrzędną zasadą kompozycyjną rozstrzyga o walorach współczesnej architektury willowej. Kształt bryły oraz sposób komponowania elewacji mają związek z obraną przez architekta koncepcją przestrzenną. Forma architektoniczna willi dopełniona przez materiały, w relacji do otoczenia, decyduje o zespoleniu, neutralności lub akcentowaniu architektury willi $\mathrm{w}$ otaczającej przestrzeni. Relacja pomiędzy architekturą, a miejscem wiąże się każdorazowo z subiektywnym podejściem architekta do kontekstu, mającym swe odzwierciedlenie w indywidualnym charakterze współczesnej architektury willowej.

Myśląc o synergii w architekturze, nasuwa się pojęcie doskonałości i unikalnej jakości dzieła, kreowanego w służbie Piękna lub w poszukiwaniu oryginalności, jawiącej się współcześnie jako wiodąca kategoria estetyczna. Jakość, a zarazem wartość współczesnej architektury willowej ma związek z formą i kompozycją architektoniczną, doborem konstrukcji i materiałów, sposobem komponowania elewacji, detalami architektonicznymi cechami odzwierciedlającymi charakter i indywidualizm twórcy dzieła. Architektura willowa może stanowić czynnik podnoszący rangę miejsca[14]. Finezja formy i sposób wkomponowania bryły w przestrzeń parceli, decyduje wraz z istniejącymi uwarunkowa- 
niami naturalnymi i kulturowymi o synergicznej pełni i niepowtarzalności lokalizacji. Potrzeba identyfikacji człowieka i przestrzeni ma związek z poszukiwaniem tożsamości miejsca. Jesteśmy rozdarci między pragnieniem uzyskania kontroli nad naszymi zmystami $i$ zastygnięcia $w$ wyznaczonych im ramach a odruchem nakazującym przyznać, $w$ jak wielkim stopniu nasza tożsamość jest trwale zwiąana $i$ ksztaltowana przez miejsce, $w$ którym żyjemy[15]. Wartość przestrzeni dzielnicy willowej i szerzej miasta zależy zatem od konkretnej budowli architektonicznej, stojacej wotoczeniu. O wartości i wyjątkowości przestrzeni stanowi jej odrębny charakter, który nigdy nie bywa prosty, a w naszych czasach niewatpliwie jest pełen złożoności i sprzeczności, nie znaczy to jednak, by byt pozbawiony struktury czy znaczenia[2, 68-69]. Synergiczna pełnia współczesnej architektury willowej i miejsca buduje tożsamość, stanowiąc o unikalnej jakości przestrzeni zwanej Duchem Miejsca.

\section{Literatura}

1. Kozłowski D. Dzieło architektoniczne w przestrzeni miasta - o formie, kontekście, użyteczności. Czasopismo Techniczne 15(6-A) (2008) 86-89.

2. Norbert-Schulz Ch. Bycie, przestrzeń i architektura. Warszawa 2000, s. 28-31.

3. Monestiroli A. Tryglif i metopa. Kraków 2009, s. 32.

4. Kozłowski D. Miejsce szuka formy, forma szuka funkcji. „Pretekst” Zeszyty Katedry Architektury Mieszkaniowej 3 (2010) 7.

5. Monestiroli A. Architektura rzeczywistości. „Pretekst” Zeszyty Katedry Architektury Mieszkaniowej 3 (2010) 80.

6. Norberg-Schulz Ch. Znaczenie w architekturze zachodu. Warszawa 1999, s. 204.

7. Kozłowski D. O pięknie architektury (wspótczesnej) - uwagi o ułomności rzeczy użytecznych. Czasopismo Techniczne 13-A (2007) 77.

8. Jodidio P. Architecture now! Singapore 2004, s. 304-313.

9. Bradbury D. The iconic house. Architectural master works Since 1900. London 2009, s. 336.

10. Adam H. Betonwyrfel mit Elefantenhaut. Haus Susenberg In Zürich. Baumeister 9 (2007) 4857.

11. Wohnhaus in Zürich. Detail 1-2 (2008) 32-36.

12. Kozłowski D., Misiągiewicz M. Willa Bâteau-Bâteau. Rezydencje 2 (1996/1997) 64 - 65.

13. Misiągiewicz M. Przestrzeń estetycznie otwarta. Czasopismo Techniczne 15(6-A) (2008) 105106.

14. Białkiewicz A. Między forma plastyczna a architektoniczna. Środowisko Mieszkaniowe 7 (2009) 8-10.

15. De Botton A. Architektura szczęścia. Warszawa 2006, s. 11. 


\title{
Synergistic completeness of contemporary villa architecture in urban space
}

\author{
Monika Gala-Walczowska \\ Department of Housing Architecture and Architectural Composition, \\ Institute of Architectural Design, Faculty of Architecture, Cracow University of Technology, \\ e-mail: mgala-walczowska@pk.edu.pl
}

\begin{abstract}
A high quality residential area is a unique space in landscapes of historic European cities. Its specific beauty is constituted by natural value, urban composition, but, above all, quality of architecture. Both historically and contemporarily architecture of a town house has been connected with a garden and has been characterized as representative. The synergistic completeness of contemporary villa architecture is constituted by postmodern interpretation of a place. Its character commonly provokes architects into searching of connections between a building, a landform and a surrounding landscape, in scenic and spatial connections with a city or otherwise by visual separation from a street or by selective view cropping. The quality of the presented examples of contemporary villa architecture is defined by individualism of the authors. Each of the architects interprets a place differently and suggests an appropriate architectural form of a house in a space of a high quality urban residential area. The brick villa in Berlin by Davida Chipperfielda is architecture of symbiotic completeness with a place. House R128 in a high quality residential area of Stuttgart is an example of architectural game with a landform, created by the architect and, at the same time, the owner of the house - Werner Sobka. House Susenberg in a high class residential area of Zurich determines a dialog of architecture and urban space. Architecture of Villa Băteau-Băteau in Cracow by Dariusz Kozłowski and Maria Misiągiewicz, might be called a sign in space of high quality residential area. The synergistic completeness of a town house and urban landscape coexistence constitutes a unique quality of a place, called a Spirit of a Place.
\end{abstract}

Keywords: contemporary architecture, town house, architectural form and composition, synergy in architecture. 